\title{
China's Strategic Foreign Initiatives Under Xi Jinping
}

\author{
An ASEAN Perspective
}

Aileen S. P. Baviera

\begin{abstract}
This article provides a summary of China's new strategic foreign initiatives under Xi Jinping's leadership. These initiatives include the "One Belt, One Road" proposal, the establishment of the Asian Infrastructure Investment Bank, and calls for a "New Asian Security Concept" as well as for "a new type of major power relations." In a localized Southeast Asian context, they are operationalized, as projects under the so-called 21st Century Maritime Silk Road proposal, a " $2+7$ cooperation framework for China-Southeast Asia relations," and the so-called "dual track" approach to the management of the South China Sea disputes. These initiatives are expected to provide a favorable external environment for the attainment of the "Chinese dream" and to pave the way for China to emerge into a position of global power and leadership. The article mainly focuses on
\end{abstract}

Aileen S. P. Baviera is Professor of China Studies and International Relations at the Asian Center, University of the Philippines. Her address is Rm 204-A, GT-Toyota Hall Asian Cultural Center, Magsaysay St corner of Katipunan Ave, U.P. Diliman, Quezon City 1101, Philippines. She can also be reached at aileen.baviera@gmail.com.

This article is based on a presentation delivered at the 29th Asia Pacific Roundtable, organized by the ASEAN Institutes for Strategic and International Studies, in Kuala Lumpur, Malaysia on June 2, 2015.

(c) 2016 World Century Publishing Corporation and Shanghai Institutes for International Studies China Quarterly of International Strategic Studies, Vol. 2, No. 1, 57-79

DOI: 10.1142/S2377740016500032 
what these initiatives may be signaling to China's neighbors, and the subsequent implications for Southeast Asia and its relations with China. There are, for instance, some doubts as to whether China can be a reliable provider of security and stability as public goods in its own region if China itself is a key party in the territorial contentions and power rivalries that could be likely causes of conflict. The fact that China is still trying to defend primordial territorial and cultural-ideational interests, settle historical scores, and find an effective model for its domestic politics and governance that will serve its increasingly globalized economy, indicates that China may not be ready yet to make the sacrifices and compromises that will be required of regional — let alone global — leadership.

Keywords: Chinese foreign policy; regional leadership; ASEAN; regional security; South China Sea.

\section{Introduction}

The current leadership of China has presented the international community with a vision of its desired global and regional order through the enunciation of many new strategic foreign initiatives. Some of these initiatives relate to the broad sweep of China's Asia-Pacific policy, while others appear more particularly directed at Southeast Asian countries or even at specific issues such as territorial disputes in the South China Sea. While not all can be considered equally "strategic" in terms of possible long-term or comprehensive impact, they all appear to be parts of a cohesive plan designed by China to achieve certain desired outcomes pertaining to the strategic environment in its neighborhood.

This article provides a summary of China's new strategic foreign initiatives under Xi Jinping's leadership and their apparent objectives, based on Chinese official pronouncements and analyses by both Chinese and foreign scholars. "New strategic initiatives" here refer to the vision, programs, and projects that China has pursued or proposes to undertake as the means for securing its long-term diplomatic and security interests in its neighborhood or "periphery." While the concept of "strategy" usually stresses the interactions of international politics, diplomacy, economics and military power, this article looks primarily at the first three and does not deal as much with military power, which could be the subject of separate analyses. Moreover, it focuses primarily on Southeast Asia. The most 
prominent of these initiatives are the "One Belt, One Road" ("Belt and Road") proposal, the establishment of the Asian Infrastructure Investment Bank (AIIB), and the calls for a "New Asian Security Concept" and "a new type of major power relations." Perhaps less profound and ambitious but no less important are the so-called " $2+7$ cooperation framework for ChinaSoutheast Asia relations for the next decade," as well as a "dual track" approach and hopes of building a "community of common destiny" in relation to the South China Sea region.

This study locates these pronounced foreign policy thrusts within the shift in attitude of the Chinese government since 2010 but especially since $\mathrm{X}$ Jinping took the helm in late 2012. Xi Jinping's articulation of the "Chinese dream" of national rejuvenation, and the apparent abandonment of Deng Xiaoping's earlier exhortation for Chinese leaders to "hide capacities while biding their time" mark this shift. This new stance is evidenced by China's particularly active demonstration of its growing economic and military strength, much bolder assertion of sovereignty and maritime rights, and pointed challenges to what it perceives to be attempts by other big powers, principally the United States, to contain China's rise.

The article then provides some argument seeking to explain the shift in China's foreign policy behavior. It presents analyses of what may be deduced as the directions and principal objectives of China behind these new undertakings. Finally, it briefly explores the possible implications of China's new thinking for its relations with Southeast Asia. For instance, how might Southeast Asians confront the shifting geopolitical environment where China's rise and foreign policy proactiveness might undermine both the post-World War II security order built on U.S.-centered bilateral military alliances and ASEAN-centered multilateralism and cooperative security arrangements?

\section{New Strategic Initiatives and the "Chinese Dream"}

The barrage of China's new foreign initiatives do reflect some continuities with previous leaderships, but they also mark an important departure from the earlier worldview and attitude of China's ruling elite. Xi's government in particular appears to have abandoned Deng Xiaoping's policy of "hiding capacities while biding time" in foreign policy matters, though changes had already begun prior to Xi Jinping's accession to the top leadership in 2012. 
After decades of restraint, maintaining a low profile and deliberately staying away from exercising leadership of the developing countries or leading any coalition in the international front, China began to not only expect but in some ways demand that other countries begin to pay heed to China's interests, accommodate its preferences on matters of regional orderbuilding, and accord it a position of privilege in the regional hierarchy.

In accounting for the shift in China's foreign policy stance to a more assertive posture, there are various possible reasons. One theory is that a political opportunity arose with the global financial crisis of 2008 bringing chaos to Western economies and eventually contributing to their political dysfunction. In contrast, China had surpassed Japan as the world's second largest economy in 2010, and euphoria from the hosting of the 2008 Olympics had raised confidence and inspired nationalist sentiments. ${ }^{1}$ In China, pub-

Whatever the explanation for $\mathrm{Xi}$ Jinping's new strategic initiatives, China seems determined to maintain a stronger foreign policy stance. lic expectations increased that their richer, stronger country should be a more influential one to be treated with deference by other states. After over thirty years of rapid growth, China had indeed moved up in the hierarchy of power and wealth that mattered very much to its leaders, still smarting from the historical memory of the "Hundred Years of Humiliation." The goals of modernization and attaining relative affluence finally seemed within reach; the "Chinese dream" was no longer so distant. There was a window of opportunity open to China to extend its own influence and attain greater respect and status in the international community. Rather than bide their time, Chinese leaders decided to seize the moment; rather than continue to hide capacities, they began to show the world that China had become strong and powerful and ready to claim its place among the world's most influential players.

Another theory is that as the U.S.-led Global War on Terror was winding down in Afghanistan and Iraq (not having attained its purposes

${ }^{1} \mathrm{~A}$ similar argument is made by Wang Yizhou of Peking University. See Wang Yizhou, “China's New Foreign Policy: Transformations and Challenges Reflected in Changing Discourse," The ASAN Forum, March 21, 2014, http://www.theasanforum.org/chinas-newforeign-policy-transformations-and-challenges-reflected-in-changing-discourse/. 
and even leading to new types of problems, in the view of many), the U.S. would inevitably turn its attention once more to China, where such attention had been prior to 9/11. This American "pivot to Asia" began to manifest quietly since 2009 before being announced publicly in 2011, and involved mainly an invigoration of U.S. alliances and developing new security partnerships particularly in China's maritime periphery. Only later did the economic component of this U.S. rebalance to Asia - the Trans Pacific Partnership (TPP) - become part of the official policy, but by then, many among the Chinese elite had developed a deep belief that the pivot was directed against China and kept raising alarm bells of a new U.S. "containment." Therefore, the new strategic initiatives and the much more pronounced assertiveness, including policies and programs beefing up its maritime power, are China's responses and counterfoils to the U.S. pivot.

Yet another theory would attribute China's new posture to the preferences and leadership style of $\mathrm{Xi}$ Jinping himself, as well as the imperatives of power consolidation in his first years in office. The phrase "Chinese dream" was first mentioned by Xi Jinping a few days after taking over as the new General Secretary of the Communist Party of China (CPC). While the term remains loosely defined, it is definitely associated with the elements of "national rejuvenation, improvement of people's livelihoods, economic prosperity, construction of a better society, and military strengthening." $^{2}$ It appears to offer continuity with past reform efforts, including Jiang Zemin's "Three Represents" and Hu Jintao's "Scientific Development" as well as "Harmonious Society" and "Harmonious World" concepts. Xi Jinping now talks about the "Four Comprehensives" which involve building the moderately prosperous society that Deng Xiaoping set as a goal in 1979, deepening social reforms, implementing the rule of law, and strengthening Party discipline. To be more specific, the "Chinese dream" is a link to the future by setting goals in anticipation of the "two centennials": becoming a "moderately well-off society" by doubling its 2010 GDP and per capita income in 2021, when China celebrates the centennial of the founding of the CPC, and the goal of becoming a "modern socialist country" by 2049, the 100th anniversary of the establishment of the People's Republic of China.

${ }^{2}$ Zha Daojiong, "China's Economic Diplomacy: Focusing on the Asia Pacific Region," China Quarterly of International Strategic Studies, Vol. 1. No. 1 (April 2015), pp. 85-104. 
$\mathrm{Xi}$ also spoke of an "Asia Pacific dream" when he was host of the APEC in 2014, stressing the need to stay ahead of global developments and for the countries of the Asia Pacific to make greater contributions to the well-being of mankind. As he passionately announced, "Through having higher levels of economic vibrancy, free trade and investment facilitation, better roads, and closer people-to-people exchanges, countries and peoples of the region can develop a better sense of shared destiny." ${ }^{3}$

\section{China's New Strategic Foreign Initiatives}

\section{One Belt, One Road (Belt and Road Initiatives)}

The establishment of the Silk Road Economic Belt and 21st Century Maritime Silk Road ("One Belt, One Road" or "Belt and Road") was proposed by Xi Jinping during his visits to Central Asia and Southeast Asia in October 2013. He laid out a vision of connectivity involving countries of Asia, Europe and Africa, where building and strengthening infrastructure links (including highways, railways, and ports, among others) are expected to promote the cross-border coordination of development strategies, opening of new markets, and enhanced cultural and scientific exchanges, bringing mutual benefit and win-win outcomes for over four billion people. The notion of a "belt" that will stretch from China to Europe will involve efforts to jointly build a Eurasian land bridge and make use of international transport routes, core cities and economic industrial parks as "cooperation platforms" between China and states along the route. ${ }^{4}$ The "maritime silk road," on the other hand, aside from enhancing infrastructure connectivity of China with Southeast Asia and South Asia, calls for the promotion of free trade, development cooperation, and in particular, cooperation on "marine economy, maritime connectivity, marine environment, marine safety and security, and cultural and people-to-people exchanges on the sea." ${ }^{5}$

${ }^{3}$ Xi Jinping, "Seek Sustained Development and Fulfill the Asia-Pacific Dream," APEC China, November 13, 2014, http://www.apec-china.org.cn/41/2014/11/13/3@2580.htm.

4 "Vision and Actions on Jointly Building Silk Road Economic Belt and 21st Century Maritime Silk Road," National Development and Reform Commission website, March 28, 2015, http://en.ndrc.gov.cn/newsrelease/201503/t20150330_669367.html.

${ }^{5} \mathrm{Xu} \mathrm{Bu}$, "Maritime Silk Road Can Bridge China-ASEAN Cooperation," Jakarta Post, August 5, 2015, http://www.thejakartapost.com/news/2015/08/05/maritime-silk-road-canbridge-china-asean-cooperation.html\#sthash.d78aGkAY.dpuf 
This ambitious infrastructure connectivity initiative is also seen to be driven by three needs of China: (1) access to energy resources, (2) security along its border provinces, and (3) new markets for Chinese goods and services, especially at the current time of excess capacity amidst reduced demand from the West. ${ }^{6}$ To fund "Belt and Road" projects, China has established a US\$40 billion Silk Road fund, and a US\$100 billion Asian Infrastructure Investment Bank, as well as pushed for a New Development Bank (also known as the BRICS bank) led by emerging economic powers.

\section{Asian Infrastructure Investment Bank (AIIB)}

The AIIB was first mentioned by President $\mathrm{Xi}$ Jinping and Premier $\mathrm{Li}$ Keqiang during visits to Southeast Asia in October 2013, as a multilateral lending institution that will prioritize the infrastructure needs of developing Asian countries and help China implement its new "Belt and Road" initiatives. Some observers have compared the "Belt and Road" and AIIB together to the post-war European "Marshall Plan," while others see AIIB as designed to compete for financial leadership with the U.S.-led World Bank (WB) and the Japan-led Asian Development Bank (ADB). Joined by 57 founding members at the signing ceremony of its articles in June 2015, AIIB aims to: (1) foster sustainable economic development, create wealth and improve infrastructure connectivity in Asia by investing in infrastructure and other productive sectors; and (2) promote regional cooperation and partnership in addressing development challenges by working in close collaboration with other multilateral and bilateral development institutions. Areas of focus include energy and power, transportation and telecommunications, rural infrastructure and agriculture development, water supply and sanitation, environmental protection, urban development and logistics, etc. ${ }^{7}$

AIIB is a very significant initiative in light of the projected US $\$ 8$ trillion worth of infrastructure needed in the Asian region, and for which financing by traditional credit sources such as the WB and ADB is insufficient. There have

${ }^{6}$ Theresa Fallon, “The New Silk Road: Xi Jinping's Grand Strategy for Eurasia," American Foreign Policy Interests, Vol. 37, No. 3 (May/June 2015), pp. 140-147.

7 “What is the Asian Infrastructure Investment Bank," AIIB website, http://www.aiib. org/html/aboutus/AIIB/. 
been concerns expressed that AIIB, together with the "Belt and Road" projects, would be used by China to gain geostrategic influence over its neighbors at the expense of the United States or other powers. Some sources also articulate fear that a Chinese-led financing mechanism would be prone to poor governance practices, despite China's assurances that ultimately, AIIB's rules and procedures shall be a collectively designed multilateral undertaking.

\section{The New Asian Security Concept (NASC)}

At the Shanghai Summit of the Conference on Interaction and Confidence-Building Measures in Asia (CICA) in May 2014, Xi Jinping spoke of the need to build a new cooperative regional security architecture for Asia based on "winwin" formulas. Borrowing heavily from postCold War Track Two discourses on security, and reiterating concepts that the Jiang Zemin
China's many new initiatives constitute a grand strategy in political, security, economic and cultural arenas. government had already professed in the mid-1990s, ${ }^{8}$ Xi Jinping outlined the elements of the desired architecture as "common security" (i.e., universal, equal and inclusive security), "comprehensive security" (i.e., attention to both traditional and non-traditional security challenges), "cooperative security" (i.e., security of individual countries as well as of the region through dialogue and building strategic trust, starting with cooperation in less sensitive areas); and then added to this the idea of sustainable security (linking development and security). The approach emphasizes mutual trust, mutual benefit, equality and coordination. ${ }^{9}$

$\mathrm{Xi}$ also underscored Asia's responsibility for addressing its own region's security challenges, and he called for the establishment of an Asiawide security forum where neighbors can discuss cooperation against the "three forces of terrorism, separatism, and extremism" (reflecting China's internal security concerns), as well as cooperation in law enforcement, emergency response and even intra-Asian civilizational dialogue. The New

${ }^{8}$ Joshua Eisenman, Eric Heginbotham, and Derek Mitchell, eds., China and the Developing World: Beijing's Strategy for the Twenty-First Century (Oxford: Routledge, 2007).

${ }^{9}$ Xi Jinping, "New Asian Security Concept for New Progress in Security Cooperation," Chinese Ministry of Foreign Affairs website, May 21, 2014, http://www.fmprc.gov.cn/ mfa_eng/zxxx_662805/t1159951.shtml. 
Asian Security Concept pointedly excluded the United States as a nonAsian country. Its calls for Asian solutions to Asian security issues were no doubt intended to undermine the role of the U.S.-led system of alliances that had heretofore provided a semblance of stability in the Asia Pacific, but which China increasingly felt were being targeted against it.

An analyst from the China Institute for International Studies hints at the reason behind its government's call for Asians to come together on security issues:

... the U.S. attempts to build up a so-called "encirclement ring" to contain and deter China. This kind of conduct by the U.S. is nothing but a product of the zero-sum game of the Cold War mentality, which can easily invite new challenges to the stability and development of various countries in the Asia-Pacific region. ${ }^{10}$

Picking up on this theme of Asian security for and by Asians, one Western observer commented in turn that: "This concept appears to be an effort to redefine the idea of security on terms that cast China as a regional security provider and the United States as an over-assertive outsider that threatens to undermine regional security." ${ }^{11}$

\section{New Type of Great Power Relations (NTGPR)}

NTGPR (variedly translated as "New Type of Major Power Relations" and "New Model of Major Country Relations") was first introduced by then Vice President Xi Jinping during his visit to Washington in February 2012, and fleshed out more specifically at the Sunnylands Summit with U.S. President Obama in June 2013. ${ }^{12}$ It refers to China's proposal that its

${ }^{10}$ Jiang Zhida, "Asian Security Concept and Its Implications for Regional Order: From a Normative Perspective," China Institute of International Studies website, November 24, 2014 http://www.ciis.org.cn/english/2014-11/26/content_7398414.htm

${ }^{11}$ David Cohen, “'A Clash of Security Concepts': China's Effort to Redefine Security," China Brief, Vol. 14 No. 11 (June 4, 2014), http://www.jamestown.org/programs/chinabrief/ single/?cHash=86683f8705325a5f31654080b698b0c5\&tx_ttnews $\% 5 B t t \_n e w s \% 5 D=42465 \#$. Vj8WB2QrKgQ.

${ }^{12}$ The concept was first articulated by Chinese State Councilor Dai Bingguo to a U.S. audience at the Brookings Institution in late 2008. 
relations with the United States be characterized as "no conflict or confrontation" (i.e., escaping what many believe to be the historical pattern of rival powers resorting to hegemonic wars), "mutual respect" (i.e., accepting rather than undermine each other's social system and "core interests"), and "win-win cooperation" (i.e., benefits for both sides as well as the rest of the world). Strategic trust, practical cooperation and people-to-people contacts were seen as the key; the Asia Pacific arena was touted to be the priority. ${ }^{13}$

During the October 2015 visit by Xi Jinping to Washington, this was mentioned again but appeared to have been completely ignored by Obama. U.S. reluctance may be explained as an unwillingness to recognize Chinese core interests or its ambition to achieve equal status with the U.S., which triggered yet more nationalist Chinese pride. As one Chinese analyst noted:

While China has been making efforts to promote this new concept, the U.S. has been reluctant to embrace it for a number of reasons. What China wants to achieve with the slogan is increased status and influence, while the U.S. views a "new type of major power relations" as finding solutions to global problems. ${ }^{14}$

More importantly, the U.S. is suspicious of China's intentions in putting forward this new idea. Some scholars cite three points as reasons for China's enthusiasm for the new concept: (1) China wants equal status with the United States as superpower; (2) China wants the U.S. to recognize its core interests; (3) China is catering to domestic policy needs, namely fostering stronger nationalistic pride under the CPC leadership.

For China, the priority is to have a principled agreement with the United States to respect China's core interests such as sovereignty, security

${ }^{13}$ Wang Yi, “Toward a New Model of Major Country Relations," Brookings Institution, September 20, 2013 http://www.brookings.edu/ /media/events/2013/9/20-U.S.-china-foreign-minister-wang-yi/wang-yi-english-prepared-remarks.pdf.

${ }^{14}$ Chen Dingding, "Defining a 'New Type of Major Power Relations,"' The Diplomat, November 8, 2014 http://thediplomat.com/2014/11/defining-a-new-type-of-major-powerrelations/. 
and development, which would lay the foundation for further cooperation. But the United States considers some of China's core interests themselves as controversial, and prefers that the two sides cooperate first on specific issues, foster mutual trust in the process, and only then (if at all) define any new foundation for big power relations. ${ }^{15}$

\section{2+7 Cooperation Framework for China-Southeast Asia Relations}

Following Premier Li Keqiang's and President Xi Jinping's five-country visit to Southeast Asia in October 2013, China put forward a proposal consisting of a "two-point political consensus" and "seven proposals for cooperation" with Southeast Asia. The so-called two-point political consensus stated that the basis for promoting cooperation is deeper strategic trust and good neighborliness, and that the key to deepening China-ASEAN cooperation is by focusing on economic development and expanding mutual benefit. The seven-point proposals include signing a treaty on good-neighborliness, upgrading the China-ASEAN Free Trade Area (CAFTA) to raise bilateral trade to one trillion dollars by 2020, setting up the earlier mentioned AIIB to finance mushrooming regional connectivity projects, building a 21st century "Maritime Silk Road" and pursuing greater defense and security exchanges.

In regard to the latter, China had proposed the establishment of an "ASEAN + China" defense dialogue, but ASEAN's reaction was initially not too enthusiastic. Beijing finally organized an ASEAN-China Defense Ministers' Informal Meeting (ACDMIM) on the sidelines of the October 2015 Xiangshan Forum (a China-led security conference), during which it further launched a five-point proposal, including boosting defense ties through the continued building of security mechanisms; deepening of cooperation in functional areas ranging from humanitarian operations and military medicine science to anti-piracy and anti-terrorism; and the management of disputes including through the holding of new joint drills. ${ }^{16}$

${ }^{15}$ Chen Jimin, “China-U.S.: Obstacles to a 'New Type of Major Power Relations,"' The Diplomat, April 9, 2015 http://thediplomat.com/2015/04/china-U.S.-obstacles-to-a-new-typeof-major-power-relations/.

16Prashanth Parameswaran, "China Reveals New Proposal to Boost Defense Ties with ASEAN," The Diplomat, October 17, 2015, http://thediplomat.com/2015/10/china-revealsnew-proposal-to-boost-defense-ties-with-asean/. 
Nevertheless, ASEAN's and its member states' reactions have yet to be made clear.

\section{"Dual Track" approach in the South China Sea}

With respect to the management of the South China Sea disputes, China has all along emphasized that this is not a dispute between China and ASEAN, but between China and only some ASEAN countries. In this light, China resisted efforts by ASEAN to play a role, insisting instead on holding only bilateral

China's "Dual Track" approach signals its enduring resistance to a multilateral approach to settling South China Sea disputes. consultations with individual countries while holding on to its position that it had "indisputable sovereignty" in the area. Chinese diplomacy was also seen to be trying to prevent ASEAN member states from coming to agreement on this issue. However, ASEAN is increasingly keen to place territorial and maritime disagreements on the agenda of its dialogues with China, including negotiations leading to the 2002 Declaration of Conduct of Parties in the South China Sea (DOC), and continuing efforts to negotiate a legally binding "code of conduct (COC)."

Several ASEAN countries' trust deficit in China has in fact deepened in the last three years because of China's growing power and greater assertiveness in the enforcement of its interests, culminating in its massive island construction on seven reefs. The reef construction, alongside China's continuing control of Scarborough Reef (seized after a standoff with the Philippines in 2012) and the declaration of an Air Defense Identification Zone (ADIZ) over disputed areas in the East China Sea, are seen by many in the region as "changing facts on the ground" or altering the status quo through both military and civilian power projection. Aside from Vietnam and the Philippines, Malaysia and Indonesia became targets of Chinese unilateral assertions of territorial sovereignty as well. To address this deficit in strategic trust, as well as to undercut the impact of the Philippines bringing the maritime disputes to an international arbitration process against China's wishes and without its participation, the new "dual track approach" by China on the South China Sea calls for "relevant disputes being addressed by countries directly concerned through friendly consultations and negotiations and in a peaceful way," together with "peace and stability in the 
South China Sea being jointly maintained by China and ASEAN countries." This proposal reflects continuing resistance to multi-lateralizing the solution to the disputes, but shows cognizance that ASEAN as a whole has a legitimate stake in how the disputes affect its immediate security environment.

\section{Deconstructing China's New Strategy}

This section enumerates some interpretations that the author as an outside observer has drawn from observing Chinese statements, behavior, and interactions with other countries in recent years, especially in relation to $\mathrm{Xi}$ Jinping's new strategic initiatives and what they signal to the region and to the world. The author, in addition, strives to fathom implications for the nation-states of Southeast Asia.

First: Chinese leaders appear to envision their country growing into a power with global reach because of its global economic interests.

With its current status as the world's biggest trading nation, the second largest (and in the future, the largest) economy, and the most populous country on the planet, China lies in eager anticipation of the impending power shift when Asia reaches new prominence as the global center of economic and political power. When that moment comes, China is not only determined to be a regional power but a global one, and not just a continental power but a maritime one.

Its "Belt and Road" initiatives are part of this. From where China sits in East Asia, it looks west by land and south by sea to envisage raw material sources, markets, investment destinations, and value chains, all the way to South and Central Asia, Europe, West Asia and Africa (but not entirely forgetting the South Pacific) to build financial, commercial, and people-topeople linkages. The analogy with the ancient Silk Road aptly invokes China's past as a major source and destination of economic and civilizational influences, which we are told was devoid of aspirations of territorial conquest and armed conflict.

Especially under the situation of a "new normal", with slower economic growth and weak demand for its manufactures in the West, China's economic future will rely more on domestic consumption and opening up these new linkages. Among others, China needs new markets, sources of 
raw materials and energy, infrastructure construction contracts to absorb surplus labor and equipment now running in oversupply, and logistics hubs to seamlessly facilitate commerce. On the maritime front, it will need capability for anti-piracy and anti-terrorist operations for protection of navigational freedom and safety, as well as access to refueling and repair stations. The AIIB can help pave the way for all of these.

This economic vision may contain the justification for China's naval and air force expansion and defense modernization - such was the case in history with economic powers that came before it.

Second: China believes that to be a global power, it must have comprehensive attributes of power including capability, resources, and the opportunity and willingness to lead.

China's current crop of leaders seem to believe that the time has come for them to pursue new technological breakthroughs, inThe ultimate driver of China's more assertive posture is its rising economic power and global economic interests. cluding major military advances, to ensure the country's pride of place among the ranks of big powers. No more biding time or hiding capacities as Deng Xiaoping cautioned; no more reluctance or shying away from opportunities to lead.

They appear to think that China's accumulated power should serve its purpose, including announcing China's great achievements as well as its ambitions, and warning others not to try and get in the way. Thus, China holds military parades to show off its most advanced weapons. It sends its navy to the Gulf of Aden for anti-piracy operations; acquires an aircraft carrier that it will eventually build into a battle group (and some analysts say eventually three or four more); builds a nuclear submarine base in Hainan; and invests its scientific energies on ways to block U.S. missile defense systems.

Presenting a high diplomatic profile also sends the same message. The Shanghai Cooperation Organization (SCO), the BRICS formation, and the CICA under China's careful nurturing have all become platforms for enunciating China's alternative visions of the world order.

Third: China understands that it can only be a major power if other major powers acknowledge and accept it as an equal. 
China's proposal for a new type of major power relations may essentially be a demand that other big powers treat it as an equal, respect its core interests, and avoid going down the path of conflict that many believe to be inevitable whenever systemic power transitions take place. Carrying the collective memory of the "Hundred Years of Humiliation" that the Chinese party-state keeps alive, many among the Chinese political elite seem to believe that the United States, supported by its allies, will never agree to accord China an equal status, let alone hand over global leadership reins to China if and when the time comes as China expects.

If China cannot be at least an equal in the global institutions already in place (the Bretton Woods system being a case) or if institutions are seen to deliberately exclude or target China for isolation or containment (the TPP and U.S. alliances come to mind), then China will create its own institutions. The AIIB, BRICS New Development Bank, CICA and the New Asian Security Concept, the Xiangshan Forum, etc., can be developed into alternative China-led arrangements that may in turn try to exclude the U.S. and those deemed unfriendly to China.

Fourth: To be a leader, China knows it must cultivate followers and friends, especially in the ASEAN region.

Garnering the support of ASEAN is especially important in order for China to step up to a new role as a responsible leader. It is with ASEAN (and the rest of East Asia, in due time) that China can build a "community of common destiny." More than any other major regional actor, ASEAN has extended to China the doubt as to what China's strategic intentions are. More than any other group of countries, ASEAN's proximity, economic dynamism, strategic location for China, and thus far its avowed neutrality in big power politics make it a desirable partner for China. Moreover, ASEAN collectively is not strong enough to challenge or threaten any of the region's big powers, including China. These are ten countries that share some common principles and perspectives but otherwise do not have a common China policy. China is the major bilateral trading partner and a major source of aid and investments for some countries. However, historical animosities and territorial disputes involving some ASEAN member states persist, leading to mistrust. In addition, historical and sociocultural interactions between Southeast Asian peoples and those of China have contributed to a complexity in ties that has recently become more pronounced as China's power and regional influence grow. 
When it comes to the South China Sea territorial and maritime disputes, the resistance of a few ASEAN states to China's recent assertiveness has pushed the whole group to take the issue more seriously. China's " $2+7$ cooperation framework" and "dual track approach" bifurcate economics and security and dichotomize the resolution of territorial disputes on one hand and cooperation in the promotion of regional peace and stability on the other. But the development of China-ASEAN relations has shown the indivisibility of economic and strategic ties, as even countries that have the most intense trade and investment ties with China also have problems overcoming strategic mistrust. Meanwhile, China's island construction efforts and various littoral states' defense build-ups in the South China Sea have placed the territorial disputes up front and at the center as a main potential trigger of regional instability.

Fifth: Even among ASEAN states, China's followers must be persuaded and enticed. Respect and loyalty must be earned. Leadership means being ready to provide followers with public goods.

Soft power matters; so does public diplomacy. In international relations, China is learning the lesson that trade, investment ties, development assistance or economic favors alone do not guarantee long-term cooperation, nor bring respect or admiration. For China's economic relations to translate into political goodwill and support, it requires sustained interactions with ASEAN dedicated to confidence-building, providing security assurances, as well as attention to social needs.

The ambitious Maritime Silk Road project ultimately offers not just funds for infrastructure connectivity projects, but proposes cooperation in scientific and technological research, and launches discussions on education, health, poverty reduction, biodiversity and so on. AIIB will be the financing component but the project planning and implementation will require policy coordination, partnerships, and making use of existing bilateral and multilateral mechanisms. Ambitious as the vision is, success depends much on the readiness of other countries to embrace and work hard on this. Thus far, this is turning out to be a great challenge.

China is facing a dilemma between reassuring its neighbors and asserting its rights and interests in the region. 
Sixth, and finally: If persuasion fails, coercive diplomacy is always an option. Ultimately, being a big power is about protecting and promoting its own interests.

China's vision is clear, and part of its realist assumptions is that, being a big power in its part of the world, it will not encounter much resistance from smaller states in its periphery. Even in instances where the pursuit of its economic, sovereignty and security goals brings it into conflict with other states, China appears to believe that it has the means to prevail. That China seems to have abandoned self-restraint and pushed hard in relation to its territorial and maritime disputes with Japan in the East China Sea and with the Philippines, Vietnam, and even Malaysia in the South China Sea shows that reputational costs are no longer given as much weight as they used to be.

Exchanges with some Chinese scholars and analysts also reveal a hubristic belief that, even if some states have difficulty adjusting to a new environment where China will have become the dominant power, they will eventually get used to the inevitable reality. When push comes to shove, countries will care most about economic welfare, these analysts argue, for as long as cooperation with China can offer material benefits, perceptions of threat can be mitigated.

\section{Implications for Southeast Asia}

Restating the above narrative, this article has constructed China's new foreign strategy under $\mathrm{Xi}$ Jinping as having a softer tone but a more muscular posture. In brief, China wants to be a global power now that it has global economic interests. It has achieved much by way of capability, and is now demonstrating a willingness to lead and a readiness to assert its own interests even at high reputational cost. Power status for China means acknowledgment by other great powers as an equal, something China wants badly, does not yet enjoy, and will insist on achieving. China is in the meantime cultivating strategic followers and friends, especially in the ASEAN region, by instruments of persuasion and by offering to provide public goods. However, if persuasion fails, more coercive forms of diplomacy remain an option, as they have been resorted to before. 
For many ASEAN states, there are "dualities" in Chinese policy that give pause to their full embrace of the "Chinese dream." The first is the duality between what China says and what it does, which highlights a decline in China's credibility and a growing trust deficit between China and many of its neighbors.

The second is the duality between China's efforts to woo and charm some ASEAN countries, and its demonstration of more coercive inclinations towards others. The latter underscores China's latent influence and capacity to divide the ASEAN into those who tend to unconditionally support China's rise and those who would oppose it, a choice that few of the member states are ready to make.

How China's new power and affluence are translating into major defense upgrades, its uncompromising stance on longstanding territorial disputes (including inexplicable intransigence towards Japan), and muscle flexing through expanded presence and activity in the South China Sea, have signaled determination to achieve the strategic dimensions of the "Chinese dream," even as it pledges good-neighborliness, cooperation, and peaceful intent.

In recent years, China has extended offers of massive aid and investments particularly for Maritime Silk Road countries (through the "Belt and Road" initiatives and AIIB), and hinted at its readiness to take greater responsibility for Asian security (NASC) as well as cooperate with other big powers (NTGPR). It also continues to discuss with ASEAN the establishment of a binding COC for the South China Sea. At the same time, however, China has been deploying its newly organized Coast Guard, paramilitary and civilian militia ${ }^{17}$ to the frontlines and extreme reaches of the South China Sea in order to assert its "indisputable sovereignty" and enforce rights in an area that is not only in dispute with four ASEAN states, but also one that is vital to global trade, energy supply, as well as regional food and environmental security. Aside from Vietnam and the Philippines with whom territorial tensions for many years has led to serious fraying of ties, Malaysia and Indonesia in recent years have begun to

17James Kraska, "China's Maritime Militia Upends Rules on Naval Warfare," The Diplomat, August 10, 2015, http://thediplomat.com/2015/08/chinas-maritime-militia-upendsrules-on-naval-warfare/. 
feel similar pressures from Chinese military presence and law enforcement activities at or near the James Shoal, South Luconia Shoal, and Natuna gas fields.

ASEAN is neither

ready to accept any

major power's

dominance of

Southeast Asia, nor

willing to take sides in a big-power game.

Meanwhile, China continues to block Filipino fishermen from accessing fishing grounds in the Scarborough Shoal, and has prevented resupply and repair missions sent by the Philippine government to the Second Thomas Shoal, where a grounded ship has been functioning as a Philippine outpost since 1999. Dialogue between the two countries has effectively been suspended since the standoff between armed authorities occurred in 2012 and after the Philippines filed a case for international arbitration against China in 2013, accusing it of preventing the Philippines from enjoying its sovereign rights under UNCLOS in its maritime zones. China refuses to participate in the arbitration process, or to recognize the arbitration panel's jurisdiction, asserting that aside from sovereignty, it had enjoyed prior historic rights in the South China Sea before UNCLOS entered into force. On a more positive note, however, China has welcomed the Philippines to be part of its Maritime Silk Road and AIIB, and dialogue between both foreign ministries has resumed, in part driven by coordination on APEC matters as host countries for the 2014 and 2015 Summits.

Most significant of all, China has undertaken massive reclamation activities in its occupied features in the Spratly (Nansha) Islands, leading to the construction of facilities, ports, and airstrips of an unprecedented scale for the area. Despite China's assurances of "mainly" peaceful civilian uses of the new facilities, this has exacerbated other countries' suspicion of its military intentions, while also resulting in possibly irreversible damage to the area's fragile reef ecosystems and fisheries. Reacting to what may be a move by China to establish strategic presence and control of the area, the U.S. and Japan have stepped in to support other littoral states in building up their maritime security and defense capabilities. This, we recall, follows their own tensions with China in recent years over China's declaration of an ADIZ in the East China Sea, and some air and sea incidents between China 
and the U.S. showing disagreement over what constitute legitimate military activities at sea.

Does such a vision, or the "Chinese dream," interpreted and deduced from Xi Jinping's new strategic initiatives, converge with Southeast Asia's own concepts and preferences of regional order?

The idea of China playing a leading role in a new Asian hierarchical order, becoming a provider of public goods, balancing the influence of other big powers, or being at the center of seamlessly interconnected economic and cultural activity as apparently envisioned by the new strategic initiatives, may not be particularly objectionable from the perspective of Southeast Asia, and may even be welcomed by most. With few exceptions, Southeast Asian countries have since ancient times lived with China under a peaceful environment and enjoyed mutually beneficial trade and peopleto-people relations. Therefore, with assurances that the future will be the same, ASEAN may be prepared to offer deference and accommodation towards China.

However, there are serious concerns and questions about the future of China-Southeast Asia relations that surface as we look into the implications of both China's foreign policy assertiveness (i.e., insistence on rights and entitlements) and its proactiveness (i.e., ambitious assistance and cooperation proposals).

ASEAN was created in 1967 by post-colonial small- and middle-power states who at the time were driven to unite by a need for strategic autonomy, i.e., the desire to retain influence over their own destinies, independent of machinations and interference by big powers. During the Cold War, ASEAN's approach to autonomy was essentially to try to keep all the big powers at bay. After the Cold War, by having all the big powers engaged and balancing each other's influence, ASEAN managed to attain the same goal. The desire for autonomy has been expressed in ASEAN agreements such as the Zone of Peace, Freedom and Neutrality, support for nonalignment by key member states, and the long-held fundamental principle of "non-interference in internal affairs" as applied to ASEAN's relations with non-ASEAN states. In other words, barring a major direct threat to ASEAN from one of the big powers, ASEAN was not and is not willing to allow dominant powers to dominate Southeast Asia, nor is it ready to choose one power over the others. The worst that might result from ASEAN member states being forced to choose between big powers is that divisions would 
deepen and lead to a split, thus destroying any value that ASEAN collectively represents for the big powers.

While ASEAN

members welcome

some aspects of

China's new

initiatives, they are

cautious of China

exerting too much

influence through

"connectivity"

projects.

Will a China-led Asian regional order preserve ASEAN's strategic autonomy? What appeared to be an initial lukewarm response to China's 21st Century Maritime Silk Road initiative, in contrast to the quick embrace of AIIB, seems to indicate precisely that while China's support, resources and even leadership in some areas may be welcome, there is some discomfort at giving China free pass to intrude more robustly into their economies and territories through "connectivity" projects. Countries (or companies) are wary that having higher reliance on China for markets, investment, loans and aid will make it more difficult for them to make choices that might displease China.

Already, China has shown indications that it expects Southeast Asian nations to value their relationships with China more than their ties with the U.S. ${ }^{18}$ The narrative of China's rise and U.S. decline is one that has been so brazenly insinuated by China in ASEAN circles that later, sensing ASEAN resistance as well as the danger of a U.S. blowback, China's leaders had to back off and retreat into Xi Jinping's statement that the Asia Pacific is "big enough" to accommodate both powers. ${ }^{19}$

The 21st Century Maritime Silk Road proposal is laudable in many respects. But how do China and some ASEAN countries, the Philippines and Vietnam most especially, but also Malaysia, Indonesia and Singapore, begin to build strategic trust when recent experience shows China belittling their legitimate interests and concerns and in some cases using coercive

${ }^{18}$ Patrick M. Cronin and Cecilia Zhou “U.S. and China's Dueling Visions of ASEAN," The Diplomat August 10, 2014, http://thediplomat.com/2014/08/U.S.-and-chinas-duelingvisions-of-asean/.

${ }^{19}$ Sangwon Yoon, "Xi Tells Kerry China and U.S. Can both be Pacific Powers," Bloomberg Business, May 5 2015, http://www.bloomberg.com/news/articles/2015-05-17/xisees-room-for-both-china-u-s-as-powers-in-pacific-region. 
behavior to get its way? Can China be a reliable provider of security and stability as public goods to the region if it is itself a key party in the territorial contentions and power rivalries that are the likely causes of conflict? In its recent actions, particularly island construction activities in six reefs in the South China Sea, China seems to have made little effort to diminish perceptions of threat and has even dragged its feet on or resisted initiatives by ASEAN states to better manage the problem (such as negotiations on the COC and the arbitration suit by the Philippines).

The broader Asian security architecture envisioned by China in CICA and its proposed New Asian Security Concept (i.e., Asians managing Asian security) are obviously intended to undermine the U.S. system of bilateral alliances, now criticized by China as anachronistic remnants of a bygone era. But beyond the rhetorical flourish, will implementing such a concept not also diminish the relevance of ASEAN's security role and ASEAN centrality by undermining the East Asia Summit, ASEAN Regional Forum, and ADMM Plus - all ASEAN mechanisms in which the United States plays an important role? More importantly, will China's perceived attempts to build multilateral arrangements in Asia that keep the United States out, and similar moves by the United States to exclude China such as the TPP, bring to an end ASEAN's longstanding efforts to build more inclusive and cooperative regional arrangements?

Given the current tense security situation in the seas of East Asia, will China's continued military buildup and expansion of its Coast Guard even granting peaceful intent and responsible leadership by China - not spur a full-blown regional arms race and turn a relatively peaceful and stable region into one with high risk of armed conflict? This is in light of both the territorial and maritime jurisdiction disputes, as well as absence of clear agreement among states on what are acceptable military activities in the EEZs or airspace above disputed areas.

\section{Conclusion}

This article attempts to understand China's new strategic initiatives in foreign relations under Xi Jinping, and their implications for ASEAN. It argues that collectively, these initiatives describe a new regional and global order that China aspires toward - one where it is able to promote and protect worldwide economic interests, play a leading role in a regional 
hierarchy, enjoy the respect of other big powers and deference by smaller ones, and maximize the benefits of power and new-found wealth to retrieve its rightful place in the world and therefore finally put the narrative and the burden of the "Hundred Years of Humiliation" behind it.

The greatest obstacle to this vision is not that other countries find it difficult to accept it; it is the fact that China is also still trying to defend primordial territorial and cultural-ideational interests, settle historical scores, and find effective paths for its domestic politics and governance that will serve its increasingly globalized economy. In this regard, its leaders have shown little inclination to make the compromises and sacrifices that lasting regional leadership entails. In the perceptions of some countries in its immediate neighborhood, China offers one open hand of cooperation and at the same time a fist ready to pound. In response, these countries offer one arm ready to embrace and one poised to fend off unwanted advances. This is the basic contradiction that Xi Jinping's new strategic initiatives will need to overcome if they are to succeed. 